\title{
Unsteady filtration under maximal draw-off velocities of Tupolang water reservoir
}

\author{
Bakiev Masharif*, Djabbarova Shakhnoza, and Khasanov Khojiakbar \\ Tashkent institute of irrigation and agricultural mechanization engineers, Tashkent, Uzbekistan
}

\begin{abstract}
The article presents the results of field studies to determine unsteady filtration in Tupolang dam core. Calculations are carried out for phreatic line curve in the core of Tupolang dam under unsteady filtration for various velocities of reservoir draw-off and water yield coefficient. At the same time it has been established that the increase of velocity and time of water reservoir draw-off leads to the increase of filtration pressure, and the decrease of water yield factor leads to the decrease of filtration pressure. The increase of filtration pressure, in turn, contributes to the increase of the intensity of unsteady filtration of Tupolang dam core.
\end{abstract}

\section{Introduction}

To use and manage water resources, as well as to carry out protection measures from destructive effect of water flow, water reservoir hydrosystem construction has greatly developed. Following the development of water reservoirs, dangerous phenomena began to occur, which are related with shortcomings in design, construction, operation and imperfection of structural elements that make up hydrosystems. Construction of water reservoir hydrosystems has increased in the past century and potential threat from them has increased respectively. When designing and constructing hydrosystems, one of the most important tasks is to provide their safety. In this regard, the issues of increasing the operational reliability of hydrtechnical structures, providing their strength and stability are of particular importance. Great attention is being paid to purposeful research works, devoted to theoretical and experimental studies of unsteady filtration in Earth-fill dams, and their influence on stability of Earth-fill dam upper slope. In this regard, one of the important tasks is to improve methods of unsteady filtration design in the body and bank massifs of Earth-fill dams, determining the influence of unsteady filtration to carrying capacity of water passage structures [2-3], [5-6], [21-24].

\section{Methods}

In the research process, static data from literature review, field study data and theoretical processing of research results were used. Besides, numerical processing of data was carried

*Correspondent author: bakiev1947@rambler.ru 
out with methods of mathematical statistics, and graphical part was done using Microsoft Excel

\section{Methods}

Design velocity of water reservoir filling must be about $0.3-0.5 \mathrm{~m} /$ day, and reservoir water level draw-off velocity must be $0.3 \mathrm{~m} /$ day. The analysis of field observations gave the following:

- violations in filling and draw-off regime of water reservoir (in 2009 it took place about 10 times);

- during the year of 2010 at mean velocity of water reservoir filling velocity of $0.13 \mathrm{~m} /$ day, the maximal velocity of water reservoir filling velocity was $1.73 \mathrm{~m} /$ day, while allowable velocity was $0.5 \mathrm{~m} /$ day;

- mean velocity of water reservoir draw-off was $0.42 \mathrm{~m} /$ day and the maximal velocity of water reservoir draw-off was $0.73-1.5 \mathrm{~m}$ /day in 2010 , at this intolerable velocity, water reservoir draw-off lasted 10 days. That mostly happened due to the violation of the regime of water reservoir operation without accounting for carrying capacity of spillway structures. Calculations were carried out using V.M.Shestakov's method [1] with following boundary conditions and assumptions: core is considered to be a homogeneous earth-fill dam, erected of loamy clay soil with coefficient of filtration $\mathrm{k}_{\mathrm{ya}}=0.001 \mathrm{~m} /$ day.

- water level at the head race is taken equal to $960.0 \mathrm{~m}$;

- it is assumed that the water level at the upper prism and transition zones will decrease simultaneously with water level at head race;

- phreatic line position was determined for steady filtration at water level decrease time at head race of $\mathrm{t}=0$.

Phreatic line position after time $\mathrm{t}$ is determined using the following relationship:

$$
y_{t}=\sqrt{\left\{y^{2}-\vartheta \cdot t\left[h_{1}+h_{t} \frac{m_{1} \cdot\left(h_{1}^{2}-h_{2}^{2}\right)}{L}\right] \cdot\left[F_{(\lambda, n)}-\frac{x+m_{1} \cdot \vartheta \cdot t}{L+m_{1} \cdot \vartheta \cdot t} \cdot F_{(L, n)}\right]\right\}}
$$

Where: $\vartheta$ - mean velocity of water level decrease at head race;

$$
\left.h_{t}=h_{1}-\vartheta \cdot t ; \quad \begin{array}{l}
F_{(\lambda, n)} \\
F_{(L, n)}
\end{array}\right\}
$$

functions, determined from plots [1], where:

$$
\lambda=n \cdot \frac{x}{2 \sqrt{a \cdot t}} ; \quad \lambda_{L}=n \cdot \frac{L}{2 \sqrt{a \cdot t}} ; \quad n=\frac{m_{1} \cdot \vartheta \cdot t}{2 \sqrt{a \cdot t}} ; \quad a=\frac{k_{\Omega} \cdot h_{1}+h_{t}}{2 \mu_{\Omega}} ;
$$

Calculations are carried out for design condition with water draw-off velocities in hydrosystem $\vartheta=2.5,3.5$ and $5.0 \mathrm{~m} /$ day at times $\mathrm{t}=5,10,15,20,25,30$ days and water yield factor $\mu=0.028 ; 0.03 ; 0.032$. Calculations are given in Tables $1,2,3,4$.

Table 1. Phreatic line positions for draw-off velocity $=3.5 \mathrm{~m} /$ day and water yield factor $\mu=0.028$

\begin{tabular}{|c|c|c|c|c|c|c|}
\hline $\mathrm{x}_{\mathrm{i}}$ & $\mathrm{y}(\mathrm{t}=5$ days $)$ & $\mathrm{y}(\mathrm{t}=10$ days $)$ & $\mathrm{y}(\mathrm{t}=15$ days $)$ & $\mathrm{y}(\mathrm{t}=20$ days $)$ & $\mathrm{y}(\mathrm{t}=25$ days $)$ & $\mathrm{y}(\mathrm{t}=30$ days $)$ \\
\hline 0 & 136.66 & 111.21 & 81.664 & 39.795 & 0,0 & 0,0 \\
\hline 5 & 140.3 & 129.57 & 105.63 & 93.065 & 82.567 & 21.14 \\
\hline 10 & 134.15 & 132.59 & 121.59 & 119.07 & 114.47 & 107.11 \\
\hline 20 & 126.65 & 126.13 & 120.78 & 119.46 & 117.16 & 114.81 \\
\hline 30 & 107.76 & 107.72 & 106.8 & 106.26 & 105.95 & 105.31 \\
\hline 40 & 96.426 & 96.456 & 96.055 & 96.035 & 95.534 & 95.405 \\
\hline 50 & 83.553 & 83.557 & 83.376 & 83.428 & 83.404 & 83.48 \\
\hline
\end{tabular}




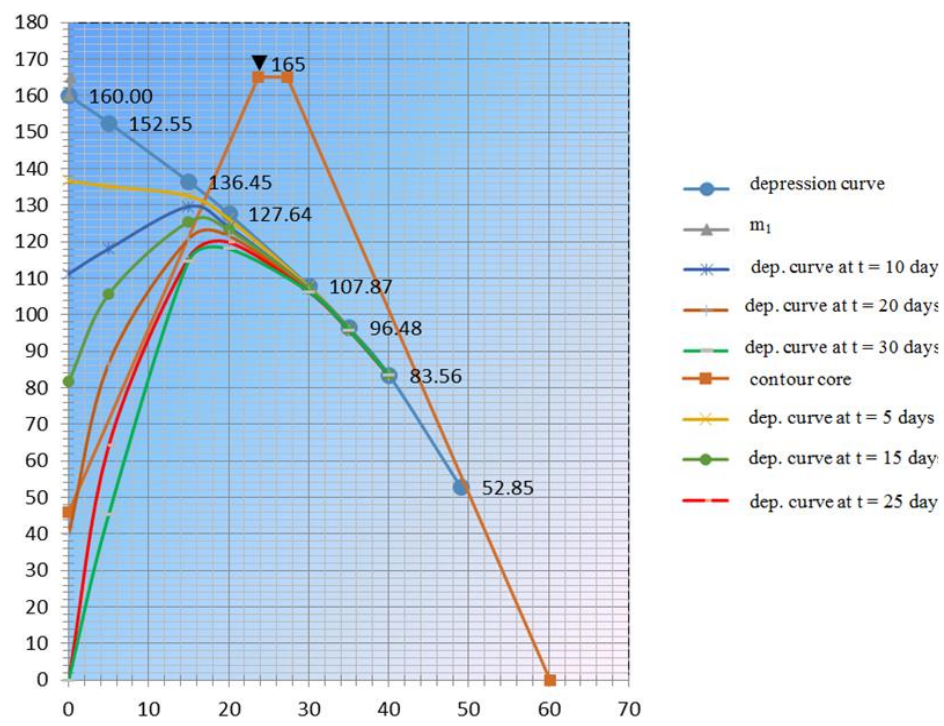

Fig. 1. Phreatic line for design condition for draw-off velocity $=3.5 \mathrm{~m} /$ day and water yield factor $\mu=0.028$

Table 2. Phreatic line positions for draw-off velocity $=3.5 \mathrm{~m} /$ day and water yield factor $\mu=0.030$

\begin{tabular}{|c|c|c|c|c|c|c|}
\hline $\mathrm{x}_{\mathrm{i}}$ & $\mathrm{y}(\mathrm{t}=5$ days $)$ & $\mathrm{y}(\mathrm{t}=10$ days $)$ & $\mathrm{y}(\mathrm{t}=15$ days $)$ & $\mathrm{y}(\mathrm{t}=20$ days $)$ & $\mathrm{y}(\mathrm{t}=25$ days $)$ & $\mathrm{y}(\mathrm{t}=30$ days $)$ \\
\hline 0 & 136,7 & 111,2 & 81,66 & 39,79 & 0,0 & 0,0 \\
\hline 5 & 139,6 & 125 & 109,8 & 91,02 & 70,99 & 31,42 \\
\hline 10 & 133,3 & 125,3 & 119,4 & 117,3 & 113,4 & 108,5 \\
\hline 20 & 126,7 & 122,9 & 120,3 & 118,9 & 117,9 & 117,3 \\
\hline 30 & 107,6 & 106,8 & 106,1 & 106 & 105,6 & 105,7 \\
\hline 40 & 96,45 & 96,15 & 95,85 & 95,68 & 95,76 & 95,88 \\
\hline 50 & 83,55 & 83,49 & 83,38 & 83,33 & 83,49 & 83,48 \\
\hline
\end{tabular}

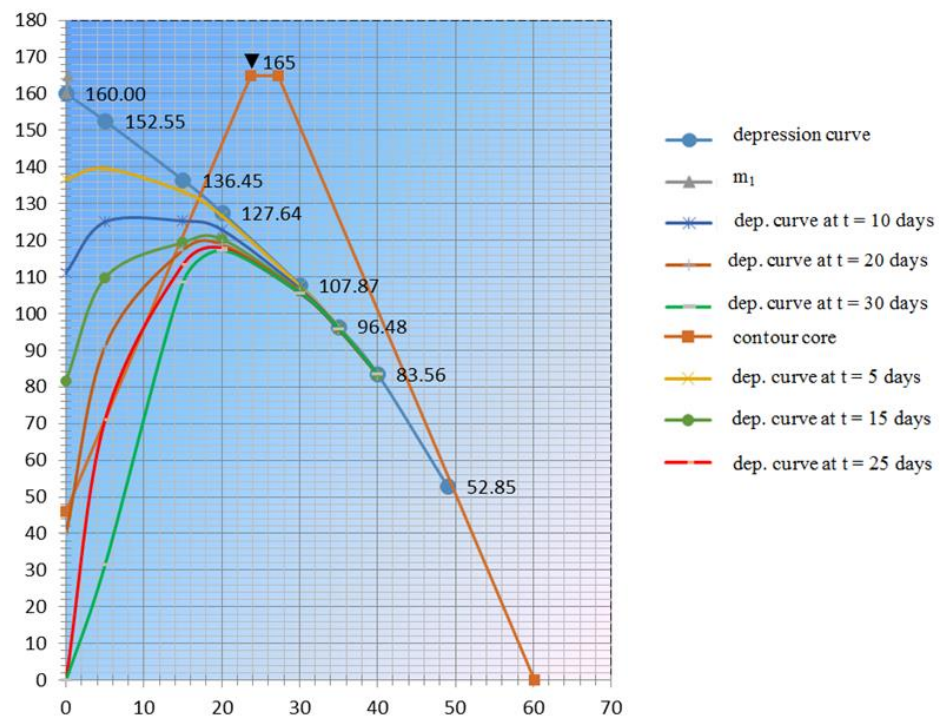

Fig. 2. Phreatic line for design condition for draw-off velocity $=3.5 \mathrm{~m} /$ day and water yield factor $\mu=0.030$ 
Table 3. Phreatic line positions for draw-off velocity $=2.5 \mathrm{~m} /$ day and water yield factor $\mu=0.032$

\begin{tabular}{|c|c|c|c|c|c|c|}
\hline $\mathrm{x}_{\mathrm{i}}$ & $\mathrm{y}(\mathrm{t}=5$ days $)$ & $\mathrm{y}(\mathrm{t}=10$ days $)$ & $\mathrm{y}(\mathrm{t}=15$ days $)$ & $\mathrm{y}(\mathrm{t}=20$ days $)$ & $\mathrm{y}(\mathrm{t}=25$ days $)$ & $\mathrm{y}(\mathrm{t}=30$ days $)$ \\
\hline 0 & 143,5 & 126,1 & 107,3 & 86,29 & 60,73 & 15,59 \\
\hline 5 & 141,1 & 130 & 119,4 & 105,2 & 94,32 & 81,46 \\
\hline 10 & 133,2 & 130,3 & 127,9 & 120,1 & 118,2 & 116,1 \\
\hline 20 & 125,5 & 123,7 & 122,6 & 117,5 & 114,6 & 114 \\
\hline 30 & 105,9 & 104,5 & 103,7 & 102,9 & 101,3 & 100,9 \\
\hline 40 & 95,54 & 94,84 & 94,6 & 94,34 & 94,23 & 93,87 \\
\hline 50 & 83,37 & 83,27 & 83,25 & 82,67 & 82,49 & 82,32 \\
\hline
\end{tabular}

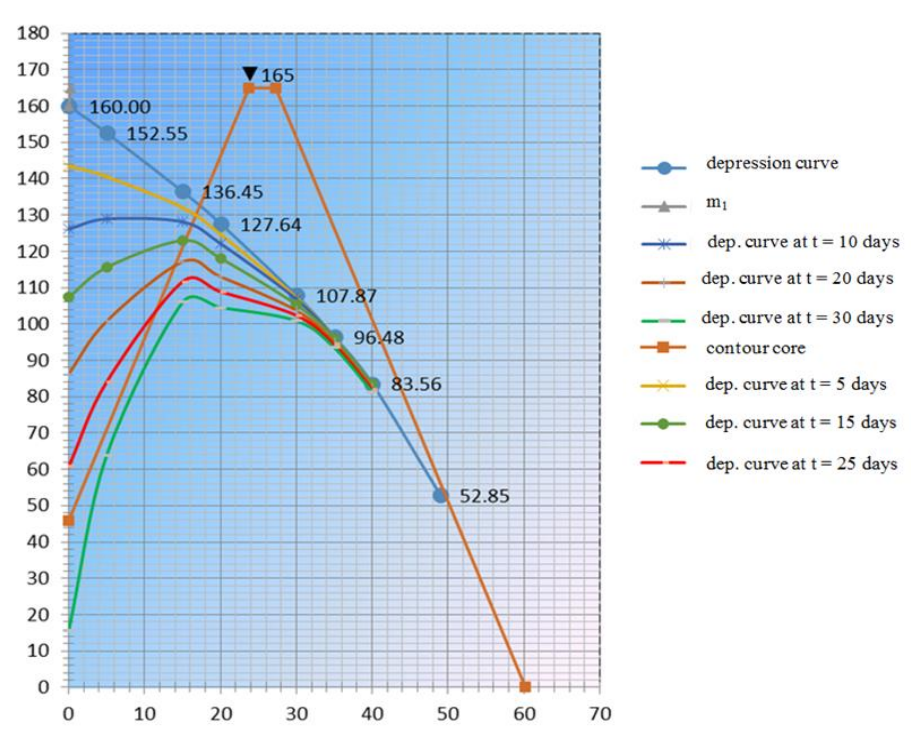

Fig. 3. Phreatic line for design condition for draw-off velocity $=2.5 \mathrm{~m} /$ day and water yield factor $\mu=0.032$

Table 4. Phreatic line positions for draw-off velocity $=5 \mathrm{~m} /$ day and water yield factor $\mu=0.032$

\begin{tabular}{|c|c|c|c|c|c|c|}
\hline $\mathrm{x}_{\mathrm{i}}$ & $\mathrm{y}(\mathrm{t}=5$ days $)$ & $\mathrm{y}(\mathrm{t}=10$ days $)$ & $\mathrm{y}(\mathrm{t}=15$ days $)$ & $\mathrm{y}(\mathrm{t}=20$ days $)$ & $\mathrm{y}(\mathrm{t}=25$ days $)$ & $\mathrm{y}(\mathrm{t}=30$ days $)$ \\
\hline 0 & 126,1 & 86,29 & 15,59 & 0,0 & 0,0 & 0,0 \\
\hline 5 & 135,1 & 119,9 & 88,58 & 86,54 & 67,86 & 58,13 \\
\hline 10 & 134,6 & 130,7 & 128,4 & 127,8 & 127,2 & 127,1 \\
\hline 20 & 127,4 & 125 & 124,7 & 124,5 & 124,4 & 124,1 \\
\hline 30 & 107,8 & 107,7 & 107,8 & 107,9 & 107,9 & 107,9 \\
\hline 40 & 96,48 & 96,48 & 96,48 & 96,48 & 96,48 & 96,48 \\
\hline 50 & 83,56 & 83,56 & 83,56 & 83,56 & 83,56 & 83,56 \\
\hline
\end{tabular}




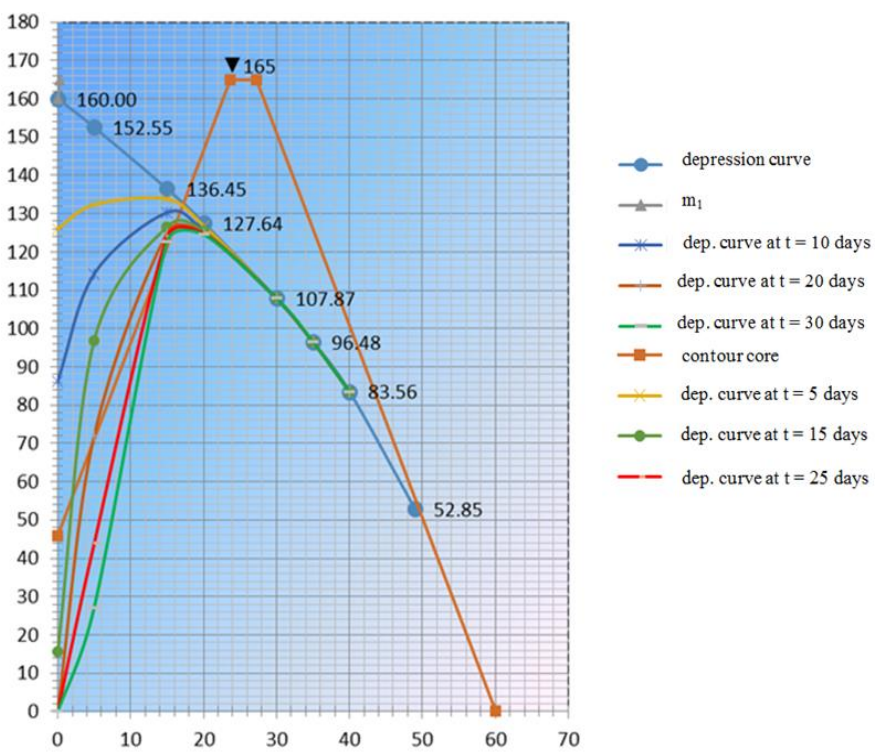

Fig. 4. Phreatic line for design condition for draw-off velocity $=5.0 \mathrm{~m} /$ day and water yield factor $\mu=0.032$

Based on data in Tables 1-4 phreatic lines in the core were constructed under conditions of unsteady filtration for various water yield factors and draw-off velocities of water reservoir, which are partially given in Figures 1-4.

As seen from Table 1 and Fig. 1, the changes in phreatic line after 5 days and 10 days are small. Further drainage of water reservoir with velocity $2.5 \mathrm{~m} /$ dah result in the increase of filtration pressure, when $\mathrm{t}=15$ days $\Delta \mathrm{H}=17 \mathrm{~m}$, when $\mathrm{t}=20$ days $\Delta \mathrm{H}=28 \mathrm{~m}$, when $\mathrm{t}=25$ days $\Delta \mathrm{H}=53 \mathrm{~m}$, when $\mathrm{t}=30$ days $\Delta \mathrm{H}=100 \mathrm{~m}$, i.e. there is significant delay of phreatic line from water level in water reservoir.

The increase of water yield coefficient from $\mu=0.03$ (Fig. 1) to $\mu=0.03$ (Fig. 2) at similar draw-off velocity $=2.5 \mathrm{~m} /$ day results in the decrease of filtration pressure from $\Delta \mathrm{H}=100 \mathrm{~m}$ to $\Delta \mathrm{H}=90 \mathrm{~m}$ at $\mathrm{t}=30$ days.

The increase of draw-off velocity from $3.5 \mathrm{~m} /$ day to $5 \mathrm{~m} /$ day increases the filtration pressure $\Delta H$ (Fig. 3, 4).

All this proves the increase of the intensity of unsteady filtration depending on the increase of water reservoir draw-off velocity increase, which may result on the damage of the stability of the upper slope and its lining.

\section{Conclusions}

Calculation results on determining phreatic line position in the core of design dam of Tupolang water reservoir shows the following: the height of seepage into the lower edge is at $\nabla 850.5 \mathrm{~m}$. According to filtration study data, given by institute "Uzgiprovodhoz" in 1981 (using EGDA device), it is at $\nabla 851 \mathrm{~m}$. The difference is $0.5 \mathrm{~m}$, which proves the accuracy of chosen design method. The increase of the velocity and time of water reservoir draw-off result in the increase of water yield factor, and its decrease result in the increase of filtration pressure. The increase of filtration pressure, in turn, facilitates the increase of the intensity of unsteady filtration in the core of Tupolang dam. 


\section{References}

1. Nedriga V.P. and others. Hydraulic structures. Designer's manual. "Stroyizdat". Moscow. 543 p. (1983)

2. Fayziyev X. The study of unsteady filtration in the upper prizm of dams with horizontal drainage. All-Union scientific-technical conference of young specialists «HPS construction in upland conditions». Presentation theses. Moscow. 1982.

3. Fayziyev X. Design of unsteady filtration in dams with core and horizontal drainage at the upper quoin. Degest: The study of tailing pits and industrial waste flow detention basins. «VODGEO» institute proceeding. Moscow. 1982.

4. M. Bakiev et al Water, MDPI 2 (2) 307-320 (2010)

5. M. Bakiev et al Environmental Earth Sciences 63(3) 447-460 (2011)

6. S. Rakhmatullaev et al Environmental Earth Sciences 68(4) 985-998 (2013)

7. A. Hamidov et al International Journal of the Commons 14(1) 16-29 (2016)

8. A. Castelleti et al Automatica 44(6) 1595-1607 (2008)

9. P. Deepa et al Australian Agricultural and Recourse Economics Society (52 rd), 48052 (2009)

10. M. Bakiev et al Improving the structural elements of earth-fill dams, providing their operational reliability and safety. Monography Voris-Nashriyot. Tashkent. 160 p. (2014)

11. M. Bakiev Irrigation and melioration journal. 14-18 (2018)

12. Wan-zhen Song et al Quaternary International. 380-381 197-206 (2015)

13. A Veksler et al Reliability, social and environmental safety of hydraulic objects: risk evaluation and taking decisions. St.Petersburg. 552p (2002)

14. Bakiev, M.R., Kirillova, E.I., Hujaqulov, R. Safety of hydraulic structures. Tashkent. $110 p$ (2008).

15. Demetris Koutsoyiannis The Encyclopedia of Water, Reliability Concepts in Reservoir Design (SW-776)

16. Bakiev, M.R., Kirillova, E.I., Talipov Sh.G., Ernazarov, N.Sh. Operational reliability and safety of hydraulic structures. Tashkent. 131p (2016)

17. Discharge hydraulic structures (discharge, spillways). Design regulations. Standartinform. 120p (2017)

18. B Bondarenko et al Hydrodynamics and Hydrotechnics $186-92$.

19. V.A.Volosuhin et al Construction and architecture 1 69-84. (2013)

20. Kh. Fayziev et al International Journal of Advanced Research in Science, Engineering and Technology 6(7) 10284-10288 (2019)

21. N Maalem et al IOP Conf. Ser.: Mater. Sci. Eng. 883012013 (2020)

22. A.A. Yangiev et al E3S Web of Conferences 97, 04041 (2019)

23. Nureddin Maalem et al IOP Conf. Ser.: Mater. Sci. Eng. 869042012 (2020)

24. A A Yangiev et al J. Phys.: Conf. Ser. 1425012015 (2019) 